\title{
Deficits in Experience-Dependent Cortical Plasticity and Sensory-Discrimination Learning in Presymptomatic Huntington's Disease Mice
}

\author{
Nektarios K. Mazarakis, ${ }^{1}$ Anita Cybulska-Klosowicz, ${ }^{2}$ Helen Grote, ${ }^{1}$ Terence Pang, ${ }^{3}$ Anton Van Dellen, ${ }^{1}$ \\ Malgorzata Kossut, ${ }^{1}$ Colin Blakemore, ${ }^{1}$ and Anthony J. Hannan ${ }^{1,3}$ \\ ${ }^{1}$ University Laboratory of Physiology, University of Oxford, Oxford OX1 3PT, United Kingdom, ${ }^{2}$ Laboratory of Cortical Plasticity, Nencki Institute of \\ Experimental Biology, 02-093 Warsaw, Poland, and ${ }^{3}$ Howard Florey Institute, University of Melbourne, Parkville, 3010 Victoria, Australia
}

\begin{abstract}
Huntington's disease (HD) is one of a group of neurodegenerative diseases caused by an expanded trinucleotide (CAG) repeat coding for an extended polyglutamine tract. The disease is inherited in an autosomal dominant manner, with onset of motor, cognitive, and psychiatric symptoms typically occurring in midlife, followed by unremitting progression and eventual death. We report here that motor presymptomatic R6/1 HD mice show a severe impairment of somatosensory-discrimination learning ability in a behavioral task that depends heavily on the barrel cortex. In parallel, there are deficits in barrel-cortex plasticity after a somatosensory whisker-deprivation paradigm. The present study demonstrates deficits in neocortical plasticity correlated with a specific learning impairment involving the same neocortical area, a finding that provides new insight into the cellular basis of early cognitive deficits in HD.
\end{abstract}

Key words: Huntington's disease; barrel; plasticity; whiskers; learning; cortex

\section{Introduction}

The pathological hallmark of Huntington's disease (HD) is extensive neurodegeneration in the striatum and the cerebral cortex (Vonsattel et al., 1985; de la Monte et al., 1988). The adult-onset form of the disease is characterized by motor symptoms, such as chorea and athetosis, as well as psychiatric symptoms, including anxiety and depression (Paulsen et al., 2001; Berrios et al., 2002). Although motor symptoms correlate with the number of CAG repeats (Snell et al., 1993), psychiatric symptoms do not (Berrios et al., 2001). Moreover, it is becoming increasingly clear that, interestingly, cognitive deficits often precede the appearance of the classical motor symptoms, such as chorea, that would normally be used to define symptom onset of the disease. For example, HD gene carriers (with a CAG repeat expansion) who were not displaying any of the clinical symptoms of Huntington's disease had significantly worse scores in the Wechsler Adult Intelligence Scale (Revised) compared with non-gene carriers (Foroud et al., 1995). Similar conclusions have also been reported in other studies (Kirkwood et al., 1999, 2000).

Initial symptoms of the disease precede neuronal loss (Von-

Received Dec. 6, 2003; revised Feb. 1, 2005; accepted Feb. 1, 2005

This work was supported by the Alexander Onassis Public Benefit Foundation, the Oxford McDonnell Center for Cognitive Neuroscience, the Medical Research Council, and the National Health and Medical Research Council (Australia). We thank Dr. Peter Hansen and Colin Blackburn for help with image analysis, Richard Leszczynski and Andrew Ladwiniec for assistance with behavioral testing, and Gill Bates for kindly providing the R6/1 mice (via The Jackson Laboratory, Bar Harbor, ME). J. Cybulski designed the sensory-discrimination apparatus, and Carolyn Hannan critically read this manuscript. We declare that we have no competing financial interests.

Correspondence should be addressed to Nektarios K. Mazarakis, University Laboratory of Physiology, University of Oxford, Park Road, 0xford 0X13PT, UK. E-mail: nm1@physiol.ox.ac.uk.

D01:10.1523/JNEUROSCI.4320-04.2005

Copyright $\odot 2005$ Society for Neuroscience $\quad$ 0270-6474/05/253059-08\$15.00/0 sattel et al., 1985), suggesting that the earliest cognitive deficits, manifest in advance of the classical motor symptoms of HD, may reflect underlying abnormalities of synaptic transmission and neuronal function. Long-term changes in the efficacy of neurotransmission, in the form of synaptic plasticity, are thought to contribute to normal cognitive processes such as learning and memory (Bliss and Collingridge, 1993). In the context of Huntington's disease, abnormal synaptic plasticity has been reported in vitro in hippocampal slices from the R6/2 HD mouse model (Murphy et al., 2000).

Various areas of the neocortex have been crucially implicated in cognitive processes such as sensory discrimination, learning, memory, planning, and decision making (Smith and Jonides, 1999; Tanji and Hoshi, 2001). Therefore, early cognitive deficits observed in HD gene carriers who have not yet developed all of the classical symptoms of Huntington's disease might be attributed to selective cellular dysfunction in specific areas of the neocortex.

The aim of the present study was to test whether, in transgenic HD mice before the onset of motor signs, there is an abnormality in neocortical plasticity correlated with performance at the behavioral level. To assess any possible cortical synaptic abnormalities, we used a plasticity paradigm involving the ability of sensory deprivation to induce cortical map plasticity in the barrel cortex of wild-type (WT) mice and rats (Kossut et al., 1993; Fox et al., 1996; Lebedev et al., 2000). We were also interested in correlating effects on barrel cortex-specific plasticity with a discriminationlearning paradigm involving only the whiskers. For this purpose, we used a modification of the Lashley jump-stand apparatus (Guic-Robles et al., 1989; Cybulska-Klosowicz and Kossut, 
2001). Successful performance of this task has been convincingly shown to depend on an intact barrel cortex (Guic-Robles et al., 1992).

Our results demonstrate that motor presymptomatic HD mice show deficits in a barrel cortex-dependent sensory-discrimination learning task, as well as deficits in barrel-cortical plasticity.

\section{Materials and Methods}

Subjects. For the experiments on experiencedependent plasticity, the mice were 8 weeks of age, and for the discrimination-learning experiments, we used 10-week-old mice. For the open field, rotarod, and photobeam arena, we used 10-, 12-, and 14-week-old mice. Mice of both sexes were used in all of the tests. The R6/1 line was generated by Gillian Bates as described previously (Mangiarini et al., 1996). Approximately one-half of each litter are wild type, and the other half are hemizygous for the HD transgene.

After weaning, all of the mice were randomly allocated to standard cages in groups of three to five (for more details of housing conditions, see below). At 6 weeks of age, the mice were anesthetized by a combination of Hypnorm (fentanyl citrate; Janssen-Cilag, Bucks, UK) and Hypnovel (midazolam; Roche, Welwyn Garden City, UK) in distilled water $(1: 1: 2 ; 2.7 \mathrm{ml} / \mathrm{kg})$. The mice were then tail tipped and PCR genotyped to determine which mice were hemizygous for the HD transgene. A microchip was inserted subcutaneously to allow identification of each mouse. The study was conducted blind to genotype, and, only when all of the data had been collected, the genotype code was broken. The experiments were conducted in accordance with the United Kingdom Animals (Scientific Procedures) Act of 1986.

Housing conditions. The mice (both HD transgenic and wild type) were randomly allocated to standard cages in groups. The cages were in a room with a $12 \mathrm{~h}$ light/dark cycle. The mice had ad libitum access to water and food, with the exception of the mice used in the behavioral training, which were deprived of food for $\sim 7 \mathrm{~h}$ before training. For all of the behavioral tests, there were 6-12 mice per group.

Open field. The open-field behavioral testing apparatus consisted of a gray box that was open at the top. The dimensions of the box were $50 \times$ $30 \times 20 \mathrm{~cm}$, and the floor was divided into $1510 \times 10 \mathrm{~cm}$ squares. Testing took place under normal room illumination. Each mouse was randomly placed in one of the four corners of the box, facing the wall. We measured for a period of $3 \mathrm{~min}$ the number of squares entered (all four paws inside the square). We also counted the number of rearing sessions (i.e., the mouse balancing on the rear paws with both front paws off the ground). After each mouse had been tested, the box was thoroughly cleaned to remove odor cues.

Rotarod. After the open-field test, the mice were tested on an accelerating rotarod. The rotating cylinder was $3 \mathrm{~cm}$ in diameter, with the cylinder divided by flanges in five compartments, allowing the simultaneous testing of up to five mice. The animals had to walk on the rotating cylinder, at an initial speed of $4 \mathrm{rpm}$. The cylinder was accelerated steadily to $40 \mathrm{rpm}$, and the time until the mouse fell from the rotarod cylinder to soft bedding below was recorded.

Clasping test. Once the sensory-deprivation paradigm and the discrimination-learning training started, the mice were tested once per week for signs of clasping. Mice displaying this sign flex their rear limbs and clasp them together over the abdomen when briefly suspended by the tail. This is an early motor symptom of Huntington's disease in mice
(Mangiarini et al., 1996; Van Dellen et al., 2000) and is thought to be independent of muscle strength and acquired motor abilities. Each test for clasping involved suspending the mouse 10 times for $3 \mathrm{~s}$ each time. If an animal retracted its rear paws in the manner described on two or more of 10 trials, it was considered to be clasping. Less than two retractions were considered nonclasping.

Locomotor activity in the photobeam arena. Coulbourn Instruments (Allentown, PA) Tru Scan photobeam arenas (model E63-10) were used to record the exploratory behavior of mice in photobeam arenas (locomotor cells) over $30 \mathrm{~min}$ test sessions. Before the weekly test sessions, mice were habituated to the arenas for 30 min periods on 4 consecutive days. Subsequent test sessions commenced 1 week from the final day of habituation. The following parameters collected by Tru Scan were selected for additional analyses: total floor plane distance traveled, time spent moving, average velocity, and number of jumps. The latter refers to the number of escape movements (jumps) from the floor plane of the arena within a time window of $2 \mathrm{~s}$. Photobeam arena behavioral data from all of the test sessions were collected using the Tru Scan 2.0 software provided by Coulbourn Instruments.

Sensory-discrimination learning. Seventeen mice of both sexes from mixed litters (WT and HD) were used for behavioral training. We used a modification of the Lashley jump-stand apparatus (Carvell and Simons, 1990), designed for rats but previously used successfully for mice (Cybulska-Klosowicz and Kossut, 2001). Briefly, behavioral training consisted of a pretraining phase and a training phase. During the pretraining phase, which lasted 2 weeks, the mice were familiarized with the apparatus, and they learned to cross a narrow gap between the "start" platform and the "choice" platform (Fig. 1) and to consume the reward. The distance between the start platform and the choice platform was progressively increased to $\sim 6 \mathrm{~cm}$. At the end of the pretraining period, no mice showed any evidence of motor disability, and all of them were able to cross the platforms and consume the rewards. 


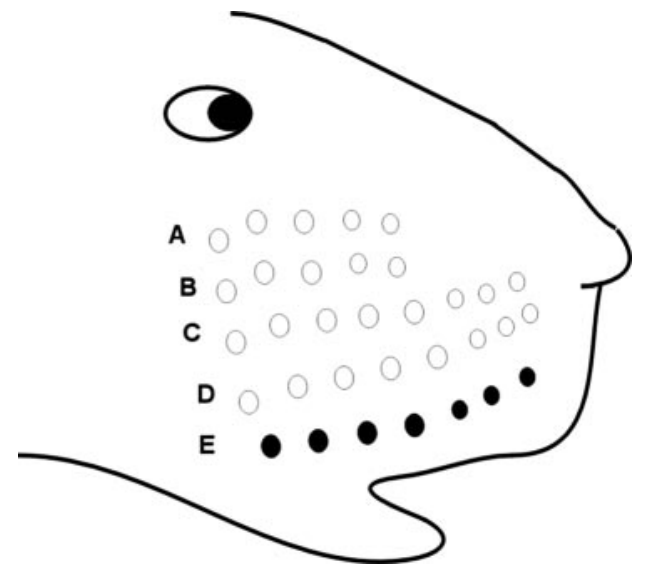

Figure 2. Sensory-deprivation paradigm. The whiskers of the right pad were trimmed (white circles), except for those in row $\mathrm{E}$ (black circles). The whiskers (rows A-D) were trimmed to the level of the fur every $2 \mathrm{~d}$ for a period of $1 \mathrm{month}$.

The training phase started after all of the mice had learned to approach and consume the reward. All of the training was performed in dim red light, to ensure that visual cues could not be used. During training, the mouse had to stretch across the gap between the start platform and the two choice platforms and, using only its vibrissas, palpate two metal grids (one with square mesh, the other with diamond mesh) (Fig. 1b). They had to discriminate between them and to climb over onto the rewarded choice platform (cued by the discriminanda) (Fig. 1c). Each mouse received 20 trials per daily session. Nine mice were rewarded for choosing the platform cued by the square grating, and eight mice were rewarded for choosing the platform cued by the diamond grating. Once the animals were on the correct choice platform (all four paws), the experimenter opened a gate and the mice had access to the reward (Fig. 1d). If the mouse chose the wrong choice platform, it was removed from the apparatus and placed in its home cage. The placement of the rewarded discriminandum to the left or right choice platform was randomized on each trial, with the restriction that the reward would not be on the same side for more than three consecutive trials. After each trial, the apparatus was thoroughly cleaned to remove any odor cues.

Results of testing were recorded as percentage of correct choices. The mouse was considered to have successfully learned the discrimination task when it reached a score of $\geq 80 \%$ (i.e., 16 correct responses of 20 , corresponding to a binomial significance of $p<0.05$ ) during three consecutive sessions.

Sensory deprivation. Fifteen mixed litters of mice (HD and WT) of both sexes were used to examine any effects on experience-dependent plasticity in the barrel cortex as a result of sensory deprivation. The deprivation procedure consisted of trimming all of the whiskers, except for row $\mathrm{E}$ (Fig. 2) of the right whisker pad, starting at 8 weeks of age. Trimming took place while the mice were restrained but awake. The whiskers were trimmed to the level of the fur every $2 \mathrm{~d}$ for 1 month (Fig. 2).

2-Deoxyglucose metabolic labeling. After the period of sensory deprivation and to visualize any possible experience-dependent changes in the functional representation of the spared row of whiskers, we used $\left[{ }^{14} \mathrm{C}\right] 2$ deoxy-D-glucose (2-DG) metabolic labeling (Sokoloff et al., 1977) as part of a protocol described previously (Siucinska and Kossut, 1996). Briefly, after an intraperitoneal injection of 2-DG (55 mCi/mmol sterile saline solution; American Radiolabeled Chemicals, St. Louis, MO) in a dose of $5 \mu \mathrm{Ci}$ per mouse, the animals were immediately placed on a neck restrainer and taped by their trunks, tail, and paws to the base of the neck restrainer, so that they were immobile but awake throughout the experiment. After a few trial procedures, the mice seemed relaxed and did not struggle in the restrainer. Using a pair of fine paintbrushes, the experimenter manually stimulated bilaterally the three large posterior whiskers of row $\mathrm{E}$ at a frequency of $2 \mathrm{~Hz}$ for $30 \mathrm{~min}$. After the 2-DG labeling, the mice received a lethal intraperitoneal dose of pentobarbitone (J. M. Loveridge, Southampton, UK) and were perfused with $4 \%$ paraformalde- hyde in phosphate buffer for $5 \mathrm{~min}$. The brain was removed, cut sagittally along the midline, and flattened following a procedure described previously (Strominger and Woolsey, 1987). The brains were then frozen in isopentane and stored in a freezer at $-80^{\circ} \mathrm{C}$. The flattened cortices were sectioned tangentially at $20 \mu \mathrm{m}$, using a cryostat at $-18^{\circ} \mathrm{C}$. Autoradiograms were made on Eastman Kodak (Rochester, NY) mammography film. Once the autoradiograms were obtained, the sections were counterstained with cresyl violet (Nissl staining) to correlate the metabolic label with the pattern of whisker-related rings of neuronal somata ("barrels") in layer IV.

Areal quantification of autoradiograms. The method for areal quantification was based on a modification of the method used for analysis of intrinsic signal optical imaging in rats described by others (Chen Bee et al., 1996). Briefly, the autoradiogram images were smoothed using a two-dimensional Gaussian smoothing kernel, with sigma 10 pixels (each pixel had a diameter of $37 \mu \mathrm{m}$ ) and a filter width of 20 pixels. Thresholding, at a value of $50 \%$ of the range between the median and maximum values, and clipping (removing the extreme top and bottom $1 \%$ of values) were applied to the filtered image to generate a viewable, intermediate-cluster image consisting of the high-contrast smoothed data overlaid with contours at the $50 \%$ value. It should be noted that clipping was used only for the purposes of data visualization to generate an easily viewable image (by enhancing the visible contrast). It was not applied to the actual data.

The experimenter subsequently selected one of the intermediate clusters that corresponded to row E. An automatic region of interest (ROI) was created, defined to be a square $\left(3 \times 3 \mathrm{~mm}^{2}\right)$ centered on the centroid of the selected cluster, adjusted translationally if necessary to fall entirely within the original filtered image. The ROI was then used to generate improved image statistics based only on the particular area of interest and avoiding other active areas and artifacts within the original image. This enabled a robust measurement of the position (centroid) of the activated region and the area of the region, which was calculated as follows: the difference between the centroid value and the median value was normalized to $100 \%$. We then calculated the contour area enclosing $95 \%$ of this normalized difference. This normalization procedure helps to minimize the effects of general variation in cortical activity that is not related to whisker stimulation (e.g., associated with slow cortical oscillations and anesthesia before perfusion). The area size of row $\mathrm{E}$ of each animal's hemispheres (control/experimental) was the average obtained, using the quantification method described above, from four to six sections in which the barrel cortex was visible.

Statistical analysis. For statistical comparisons of behavioral results, we used repeated-measures ANOVA. For areal quantification, we used a paired $t$ test or a Wilcoxon test. Finally, for 2-DG labeling intensity and centroid values, we used $t$ tests. Data are reported as mean \pm SEM. Differences were considered statistically significant at $p<0.05$.

\section{Results \\ Open field}

The performance of the HD mice in the open field was very similar to that of the WT controls (Table 1). Specifically, at 10 weeks of age, the average number of squares crossed in a 3 min open-field test (an indication of general motor activity) was 29 for WT mice and 23 for HD mice. Similarly, at 12 weeks, WT mice crossed 34 squares, and the HD mice crossed 32 squares. At 14 weeks, the WT mice crossed 25 squares, and the HD mice crossed 26 squares, indicating almost identical general mobility. Repeated-measures ANOVA revealed no difference in the number of squares crossed for the factor of age $\left(F_{(2,32)}=2.4 ; p>\right.$ 0.05 ). There was no difference between HD and WT mice (genotype) $\left(F_{(1,16)}=0.134 ; p>0.05\right)$, and, finally, there was no interaction between age and genotype $\left(F_{(2,32)}=0.46 ; p>0.05\right)$. These results show that there was no difference between WT and HD mice in the number of squares crossed in the open field between 10 and 14 weeks of age. 
Table 1. Exploratory behaviors and motor performance of wild-type and HD transgenic mice recorded from 3 min sessions in the open field and on the accelerating rotarod

\begin{tabular}{|c|c|c|c|c|c|c|c|c|c|}
\hline \multirow{2}{*}{$\begin{array}{l}\text { Exploratory parameter } \\
\text { Age (weeks) }\end{array}$} & \multicolumn{3}{|c|}{ Number of squares crossed } & \multicolumn{3}{|c|}{ Number of rears } & \multicolumn{3}{|c|}{ Time spent on the accelerating rotarod } \\
\hline & 10 & 12 & 14 & 10 & 12 & 14 & 10 & 12 & 14 \\
\hline Wild-type mice $(n=6)$ & $28.8(5.6)$ & $34(4)$ & $25(9.1)$ & $5.2(2.5)$ & $6.2(0.9)$ & $6(2.8)$ & $106.8(23.4)$ & $109.3(17.5)$ & $127.3(18.4)$ \\
\hline HD transgenic mice $(n=12)$ & $22.8(3.4)$ & $31.5(4.9)$ & $26.2(5.2)$ & $4.5(1)$ & $4.7(1.2)$ & $5.3(1.6)$ & $83(11.3)$ & $82.4(13.5)$ & $87.3(17.5)$ \\
\hline
\end{tabular}

Data are presented as mean (SEM).

Table 2. Exploratory behaviors of wild-type and HD transgenic mice recorded from $30 \mathrm{~min}$ sessions in photobeam arenas

\begin{tabular}{lccccccccccccc}
\hline Exploratory parameter & \multicolumn{2}{c}{ Distance moved $(\mathrm{cm})$} & \multicolumn{3}{c}{ Time spent moving $(\mathrm{s})$} & \multicolumn{4}{c}{ Average speed of movements (cm/min) } \\
\hline Age (weeks) & 10 & 12 & 14 & 10 & 12 & 14 & 10 & 12 & 14 \\
Wild-type mice $(n=8)$ & $7880.9(352.7)$ & $8573.1(608.7)$ & $8083.2(528.0)$ & $681.4(20.2)$ & $709.5(28.9)$ & $680.4(25.8)$ & $262.7(11.8)$ & $285.8(20.3)$ & $269.4(17.6)$ & $101.3(13.4)$ & $82.7(7.1)$ & $75.5(12.6)$ \\
HD transgenic mice $(n=10)$ & $7617.9(576.4)$ & $7366.4(596.8)$ & $7463.0(463.6)$ & $681.2(29.5)$ & $659.6(24.5)$ & $670.8(28.6)$ & $254.0(19.2)$ & $245.5(19.9)$ & $248.7(15.5)$ & $117.4(20.1)$ & $96.9(17.9)$ & $114.6(14.2)$ \\
\hline
\end{tabular}

Data are presented as mean (SEM).

Analysis of the number of rears in the open field (Table 1), an indicator of motor activity, strength, exploratory behavior, and motivation, also showed no difference between WT and HD mice between 10 and 14 weeks of age. In more detail, at 10 weeks of age, WT mice on average displayed five rearing events, and the average for $\mathrm{HD}$ mice of 4.5 rearing events was very similar. At 12 weeks, the average number of rearing events was 6 and 4.7. At 14 weeks, the averages were 6 for WT mice and, similarly, 5.3 for HD mice. Repeated-measures ANOVA revealed no significant difference for the age factor $\left(F_{(2,32)}=0.284 ; p>0.05\right)$. There was no difference for the genotype factor $\left(F_{(1,16)}=0.225 ; p>0.05\right)$. Finally, there was no interaction between age and genotype $\left(F_{(2,32)}=0.09 ; p>0.05\right)$.

\section{Rotarod}

The accelerating rotarod is used to assess motor ability and motor coordination in particular. Our results (Table 1) show that WT mice spent on average $107 \mathrm{~s}$ on the accelerating rotarod at the age of 10 weeks, whereas HD mice spent 83 s. At 12 weeks, the results were $109 \mathrm{~s}$ for WT and $82 \mathrm{~s}$ for HD mice. Finally, at 14 weeks, WT mice spent $127 \mathrm{~s}$ and HD mice spent $87 \mathrm{~s}$. Repeated-measures ANOVA revealed no significant difference in the age factor $\left(F_{(1.3,21.7)}=0.631 ; p>0.05\right.$; Greenhouse-Geisser correction applied). Similarly, there was no significant difference for the genotype factor $\left(F_{(1,16)}=2.6 ; p>0.05\right)$. Finally, there was no significant interaction between age and genotype $\left(F_{(1.3,21.7)}=0.244\right.$; $p>0.05$; Greenhouse-Geisser correction applied). These results suggest that there was no obvious difference in the time spent on the rotarod by WT and HD mice between the ages of 10 and 14 weeks.

\section{Locomotor activity in the photobeam arena}

To assess further whether the HD mice were presymptomatic at 10-14 weeks of age, we used an automated system involving photobeam arenas to record the exploratory behavior of mice (total floor plane distance traveled, time spent moving, average velocity, and number of jumps) for a longer period of time (30 min). This enabled us to examine the possibility that motor deficits might become more apparent after more extended testing. Furthermore, the use of an automated system meant that the experimenter did not need to observe the mice directly in the arena, thus avoiding possible observer-induced effects on behavioral performance.

Repeated-measures ANOVA revealed no significant differences (Table 2) between WT and HD mice for distance traveled $\left(F_{(1,16)}=0.302 ; p>0.05\right)$, time spent moving $\left(F_{(1,16)}=0.534\right.$; $p>0.05)$, average velocity of movements $\left(F_{(1,16)}=0.302 ; p>\right.$ $0.05)$, and number of jumps $\left(F_{(1,16)}=0.591 ; p>0.05\right)$. Similarly,

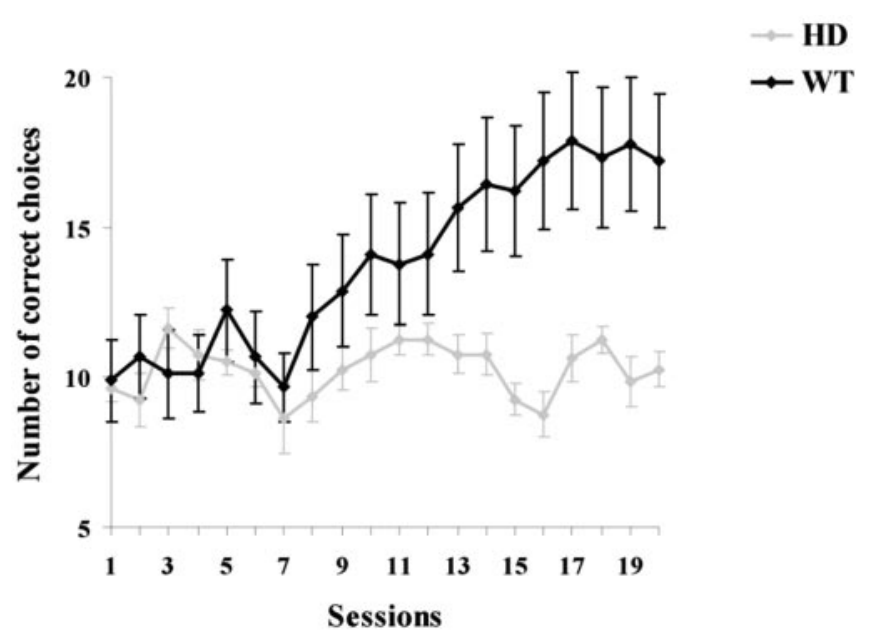

Figure 3. Huntington's disease mice presymptomatic for motor disorders show clear deficits in a barrel cortex-dependent sensory-discrimination task. None of the HD mice ( $n=8$; gray line) successfully learned the task, which involved using their whiskers to discriminate between two different tactile discriminanda in a red-illuminated dark room (Fig. 1). During the entire training period, their performance fluctuated around chance levels ( $50 \%$ or 10 correct choices of 20). In contrast, all of the WT mice steadily improved after the seventh session. All but one reached the criterion for learning the task (black line plots mean results; $n=9$ ). Repeated-measures ANOVA showed that the HD and WT mice differed significantly. Error bars indicate SEM.

there were also no significant differences attributable to age for distance traveled $\left(F_{(2,31)}=0.775 ; p>0.05\right)$, time spent moving $\left(F_{(2,31)}=0.885 ; p>0.05\right)$, average velocity of movements $\left(F_{(2,31)}=0.777 ; p>0.05\right)$, and number of jumps $\left(F_{(2,31)}=0.646\right.$; $p>0.05)$. Finally, there were no interactions between genotype and age for distance traveled $\left(F_{(2,31)}=0.210 ; p>0.05\right)$, time spent moving $\left(F_{(2,31)}=0.235 ; p>0.05\right)$, average velocity of movements $\left(F_{(2,31)}=0.208 ; p>0.05\right)$, and number of jumps $\left(F_{(2,31)}=0.953 ; p>0.05\right)$ (Table 2$)$.

Overall, the results from the open-field test, the accelerating rotarod (Table 1), and the photobeam arena (Table 2), as well as the complete absence of clasping (data not shown), confirmed that the R6/1 HD mice used in the present studies of discrimination learning and cortical plasticity (all of which were completed by 14 weeks of age) were presymptomatic with respect to motor abilities.

\section{Sensory-discrimination learning}

For sensory-discrimination learning, we used a modification of the Lashley jump-stand apparatus in which the mouse had to 

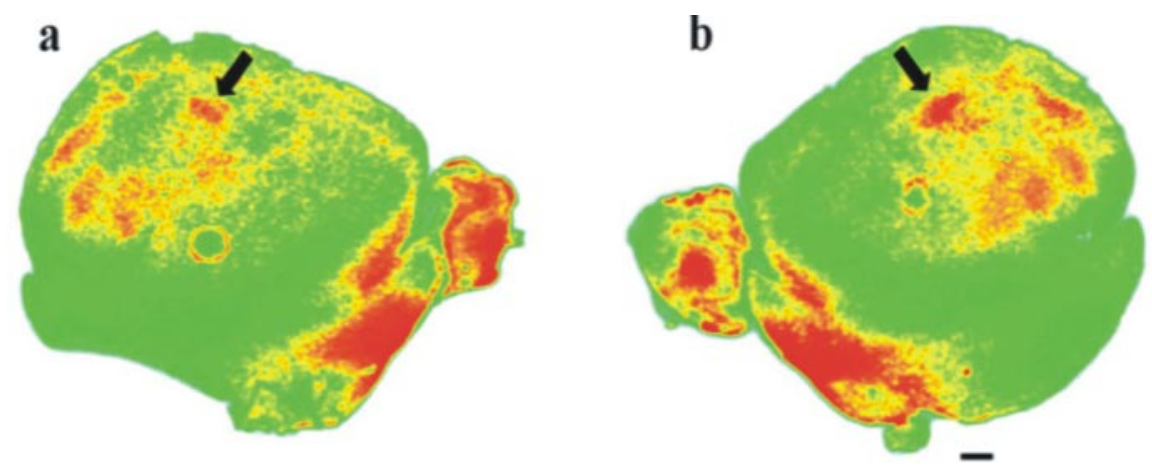

Figure 4. WT mice show expansion of functional cortical whisker representation after sensory deprivation, assessed with 2-DG metabolic labeling. Examples of 2-DG labeling of the barrel field in tangential slices of the somatosensory cortex of WT mice. $\boldsymbol{a}$, Functional representation of row $E$ of the left (control) pad (arrow) in the right hemisphere. $\boldsymbol{b}$, Functional representation of the right (experimental) row E in the left hemisphere after 1 month of sensory deprivation. Note that the functional representation of row $E$ in $\boldsymbol{b}$ is larger than that in $\boldsymbol{a}$. Scale bar, $1 \mathrm{~mm}$.
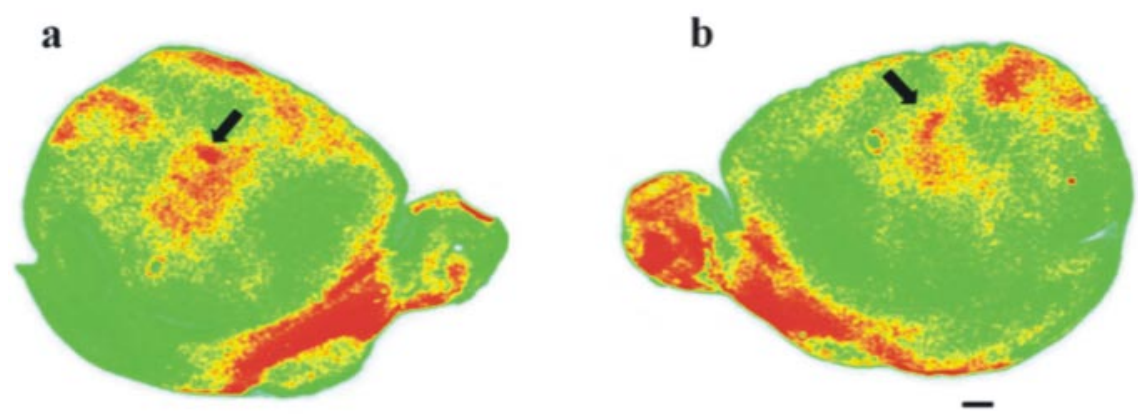

Figure 5. Presymptomatic HD transgenic mice do not show functional expansion of the spared-whisker representation after sensory deprivation, as assessed with 2-DG metabolic labeling. $\boldsymbol{a}$, Functional representation of row $\mathrm{E}$ of the left (control) pad in tangential slices of the right hemisphere (arrow). $\boldsymbol{b}$, Functional representation of the right (experimental) row $E$ in the left hemisphere after 1 month of sensory deprivation. Note that the functional representation of row $E$ in $\boldsymbol{b}$ is not expanded compared with that in $\boldsymbol{a}$. Scale bar, $1 \mathrm{~mm}$.

discriminate between two wire gratings with its vibrissas to obtain access to a food reward (Fig. 1). The experimenter was blind to genotype at the time of testing. The mice were trained every day, and all of them initially showed fluctuating performance around chance levels ( $\sim 10$ of 20 correct choices) (Fig. 3). After the seventh session, a subgroup of the mice displayed a clear and gradual increase in the number of correct choices, reaching a plateau at approximately the 17th training session (Fig. 3), whereas others remained near chance. At no point, even toward the end of the testing sessions, did any of the mice exhibit rearpaw clasping [an early motor sign of the disease in mice (Mangiarini et al., 1996)] or other motor abnormalities that might have affected the ability to perform the discrimination task (Tables 1, 2).

After the completion of behavioral training, the results of genotyping revealed that all but one of the mice reaching the criterion ( $>16$ of 20 or $>80 \%$ correct choices) were WT, whereas all of the mice that failed to reach the criterion were positive for the HD transgene. The one WT mouse that failed did manage to reach criterion twice consecutively and failed to do so only the third time. Repeated-measures ANOVA showed that overall, WT mice performed significantly better compared with HD mice (main effect of genotype, $F_{(1,15)}=62.7 ; p=0.0001$ ). There was also a significant effect of the sessions, a within-subject factor $\left(F_{(7.3,109.6)}=8.4 ; p<0.0001\right.$; Greenhouse-Geisser correction applied). Finally, there was a significant interaction between sessions and genotype $\left(F_{(7.3,109.6)}=7.4 ; p<0.0001\right)$. These results show that motor presymptomatic HD mice show deficits in a discriminationlearning task that is known to be dependent on the barrel cortex.

\section{Deficits in cortical plasticity}

The sensory-deprivation paradigm involved trimming all of the whiskers on the right side except those of row $\mathrm{E}$ for 1 month (with all of the whiskers on the left side kept intact). In the $10 \mathrm{WT}$ mice (genotype identified after the experiment), this resulted in the enlargement of the functional representation of the spared row of whiskers, as assessed with 2-DG metabolic labeling (Fig. 4). More specifically, when the threshold level was set to $95 \%$, the average areal size of row $\mathrm{E}$ of the right barrel cortex (corresponding to the left, control whisker pad) was $0.17 \pm 0.01$ $\mathrm{mm}^{2}$, whereas that of row $\mathrm{E}$ of the left barrel cortex (experimental/deprived side) was $0.2 \pm 0.009 \mathrm{~mm}^{2}(n=10 ; p<0.05$; paired $t$ test). These results suggest that sensory deprivation in WT mice induces adaptive changes in the areal size and the strength of activity in the functional representation of the spared row of whiskers.

In the five transgenic HD mice, this sensory-deprivation paradigm failed to induce functional enlargement of the experimental spared row $\mathrm{E}$ of the left barrel cortex (Fig. 5). Specifically, at a threshold level of $95 \%$, the areal sizes of the right and left row $\mathrm{E}$ representations were $0.2 \pm 0.009$ and $0.2 \pm 0.006$, respectively $(n=5 ; p>$

0.05; Wilcoxon test).

To exclude the possibility that there were differences in the overall levels of 2-DG labeling between WT and HD mice, we compared the centroid values of the right hemisphere (control side) between WT and HD mice. Additionally, we compared the ratios of labeling intensity (optical density) between HD and WT mice. The mean centroid value of WT mice $(n=5)$ was $0.43 \pm$ 0.028 (arbitrary units), and that of HD mice $(n=4)$ was $0.41 \pm$ 0.03 ( $p>0.05 ; t$ test). The ratio of labeling intensity in WT mice $(n=4)$ was $1.44 \pm 0.06$, and that of HD mice $(n=5)$ was $1.48 \pm$ 0.06 ( $p>0.05 ; t$ test). These results indicate that there was no difference in the baseline metabolic labeling of 2-DG between WT and HD mice.

During the period of sensory deprivation, none of the mice showed any symptoms of rear-paw clasping nor other motor symptoms (Tables 1,2). The above results suggest that motor presymptomatic Huntington's disease mice show deficits in neocortical plasticity in response to sensory deprivation.

\section{Discussion}

The results in the present study demonstrate that Huntington's disease mice that are presymptomatic for motor disorders exhibit sensory cortical dysfunction. Presymptomatic HD mice showed both a clear inability to learn a barrel cortex-dependent tactile discrimination task (Guic-Robles et al., 1992) and reduced plasticity of the barrel cortex in response to whisker deprivation. This 
result correlates abnormalities at the behavioral level with those at the cellular level. This is the first demonstration that HD mice show deficits in neocortical plasticity and that they occur before the onset of motor symptoms. Such functional deficits correlate with the failure of these mice in a discrimination-learning task that is dependent on the same neocortical area.

Previous work (Murphy et al., 2000) using early-onset R6/2 HD mice (Mangiarini et al., 1996) showed that, although these mice display normal basal synaptic transmission, they have abnormalities in synaptic plasticity in the form of deficits in longterm potentiation (LTP) and long-term depression (LTD) in hippocampal slices in vitro. Murphy et al. (2000) related these synaptic plasticity deficits with the poor performance of R6/2 HD mice in the Morris water maze, a hippocampus-dependent spatial memory task.

Synaptic abnormalities have also been reported by others in hippocampal and striatal slice preparations from HD mice (Hodgson et al., 1999; Levine et al., 1999; Usdin et al., 1999; Cepeda et al., 2001, 2003; Klapstein et al., 2001; Laforet et al., 2001). Some researchers (Hodgson et al., 1999; Usdin et al., 1999) have reported deficits in posttetanic potentiation (PTP) and paired-pulse facilitation, which are indicators of calciumdependent presynaptic mechanisms. This, together with evidence that expression of presynaptic metabotropic glutamate receptors (mGluR2/3) is downregulated in HD mice (Cha et al., 1998; Cha, 2000), leads to the plausible speculation that the underlying mechanism for these electrophysiological abnormalities in HD mice is abnormalities in neurotransmitter release from the presynaptic terminal ( $\mathrm{Li}$ et al., 2003). Interestingly, however, PTP is normal when in the presence of the NMDA receptor antagonist AP-5. This finding is indicative of the disruption of signaling associated with the postsynaptic NMDA receptor complex (Murphy et al., 2000).

NMDA receptors are important in experience-dependent plasticity in the barrel cortex (Jablonska et al., 1995; Rema et al., 1998). Moreover, NMDA receptors can signal via calcium/ calmodulin-dependent protein kinase II (CaMKII) (Gardoni et al., 1998) and cAMP response element-binding protein (CREB) (Hardingham et al., 2002), which are thought to be important in neocortical plasticity (Glazewski et al., 1999; Hardingham et al., 2003). Experience-dependent plasticity in the barrel cortex involves several processes, such as potentiation of responses to the spared vibrissas and suppression of those to deprived vibrissas (Fox, 2002). The final outcome of these processes, which might involve LTP/LTD-like mechanisms (Feldman, 2000), is an expansion of the functional representation of the spared row of whiskers, as shown for the wild-type mice in the present study.

There is accumulating evidence that postsynaptic signaling pathways, including those associated with NMDA receptor activation, are impaired in HD. For instance, a microarray study (Luthi-Carter et al., 2002) showed that the mRNA levels for CaMKII in the cortex of R6/2 HD mice were significantly reduced. Similarly, others have reported a reduction of CaMKII protein levels in a mouse model of HD (Deckel et al., 2001). Interestingly, neuronal intracellular inclusions, which are abundant in the HD cortex (Gutekunst et al., 1999), recruit CREBbinding protein (Nucifora et al., 2001). Therefore, the lack of neocortical experience-dependent plasticity observed in R6/1 HD mice, as shown in the present study, could be associated with disrupted intraneuronal signaling and the dysregulation of activity-dependent gene expression.

An early impairment of cortical neurotransmission and syn- aptic plasticity could explain why HD gene carriers show psychiatric and cognitive deficits before the onset of motor symptoms. Indeed, as shown in the present study, R6/1 HD mice exhibit clear cognitive deficits in a task that depends on the barrel cortex at the stage when they have a deficit in barrel-cortex plasticity and before the onset of motor signs. Human studies have shown that motor presymptomatic HD gene carriers already have cognitive deficiencies (Lawrence et al., 1998) as well as clear metabolic deficits in the cortex (Sax et al., 1996; Deckel et al., 1998).

One issue in interpreting the deficits in cortical plasticity in HD mice is the possibility that glucose metabolic machinery is impaired in these mice. To the best of our knowledge, there is no evidence suggesting an impairment of primary glucose metabolism in R6/1 HD mice. Additionally, in human HD patients with mild neuropathological features of HD (grade 1), there is no difference in the expression of the GLUT1 and GLUT3 glucose transporters compared with control subjects (Gamberino and Brennan, 1994). Moreover, our analysis of cortical plasticity, based on a within-subject approach rather than a comparison between WT and HD mice, dissociates defects in cortical plasticity from the separate issue of basal glucose metabolism. In addition, we demonstrated that there was no difference between baseline 2-DG labeling in WT and HD mice. Nevertheless, this issue could warrant additional investigation, especially in light of conflicting clinical studies concerning metabolic impairment in HD patients and presymptomatic HD gene carriers (Kuhl et al., 1982; Grafton et al., 1990; Feigin et al., 2001).

In the present study, we demonstrate that motor presymptomatic R6/1 HD mice have a striking inability to perform a cognitive task that is dependent on the very region of cortex in which we showed deficits in experience-dependent cortical plasticity. These results support the notion that cortical dysfunction occurs early in HD pathogenesis, which may explain why cognitive symptoms often precede classical motor symptoms. In the quest to elucidate the mechanisms of early cortical impairments in mouse models of HD and to identify therapeutic targets, the experimental paradigm used in our present study, involving 2-DG metabolic labeling in the barrel cortex in combination with a barrel cortex-dependent sensory-discrimination task, could provide a useful model to relate cortical and cognitive dysfunction directly in Huntington's and other brain diseases.

\section{References}

Berrios GE, Wagle AC, Markova IS, Wagle SA, Ho LW, Rubinsztein DC, Whittaker J, ffrench-Constant C, Kershaw A, Rosser A, Bak T, Hodges JR (2001) Psychiatric symptoms and CAG repeats in neurologically asymptomatic Huntington's disease gene carriers. Psychiatry Res 102:217-225.

Berrios GE, Wagle AC, Markova IS, Wagle SA, Rosser A, Hodges JR (2002) Psychiatric symptoms in neurologically asymptomatic Huntington's disease gene carriers: a comparison with gene negative at risk subjects. Acta Psychiatr Scand 105:224-230.

Bliss TV, Collingridge GL (1993) A synaptic model of memory: long-term potentiation in the hippocampus. Nature 361:31-39.

Carvell GE, Simons DJ (1990) Biometric analyses of vibrissal tactile discrimination in the rat. J Neurosci 10:2638-2648.

Cepeda C, Ariano MA, Calvert CR, Flores-Hernandez J, Chandler SH, Leavitt BR, Hayden MR, Levine MS (2001) NMDA receptor function in mouse models of Huntington disease. J Neurosci Res 66:525-539.

Cepeda C, Hurst RS, Calvert CR, Hernandez Echeagaray E, Nguyen OK, Jocoy E, Christian LJ, Ariano MA, Levine MS (2003) Transient and progressive electrophysiological alterations in the corticostriatal pathway in a mouse model of Huntington's disease. J Neurosci 23:961-969. 
Cha JH (2000) Transcriptional dysregulation in Huntington's disease. Trends Neurosci 23:387-392.

Cha JH, Kosinski CM, Kerner JA, Alsdorf SA, Mangiarini L, Davies SW, Penney JB, Bates GP, Young AB (1998) Altered brain neurotransmitter receptors in transgenic mice expressing a portion of an abnormal human huntington disease gene. Proc Natl Acad Sci USA 95:6480-6485.

Chen Bee CH, Kwon MC, Masino SA, Frostig RD (1996) Areal extent quantification of functional representations using intrinsic signal optical imaging. J Neurosci Methods 68:27-37.

Cybulska-Klosowicz A, Kossut M (2001) Mice can learn roughness discrimination with vibrissae in a jump stand apparatus. Acta Neurobiol Exp (Wars) 61:73-76.

Deckel AW, Cohen D, Duckrow R (1998) Cerebral blood flow velocity decreases during cognitive stimulation in Huntington's disease. Neurology 51:1576-1583.

Deckel AW, Gordinier A, Nuttal D, Tang V, Kuwada C, Freitas R, Gary KA (2001) Reduced activity and protein expression of NOS in R6/2 HD transgenic mice: effects of L-NAME on symptom progression. Brain Res 919:70-81.

de la Monte SM, Vonsattel JP, Richardson Jr EP (1988) Morphometric demonstration of atrophic changes in the cerebral cortex, white matter, and neostriatum in Huntington's disease. J Neuropathol Exp Neurol 47:516-525.

Feigin A, Leenders KL, Moeller JR, Missimer J, Kuenig G, Spetsieris P, Antonini A, Eidelberg D (2001) Metabolic network abnormalities in early Huntington's disease: an [(18)F]FDG PET study. J Nucl Med 42:1591-1595.

Feldman DE (2000) Timing-based LTP and LTD at vertical inputs to layer II/III pyramidal cells in rat barrel cortex. Neuron 27:45-56.

Foroud T, Siemers E, Kleindorfer D, Bill DJ, Hodes ME, Norton JA, Conneally PM, Christian JC (1995) Cognitive scores in carriers of Huntington's disease gene compared to noncarriers. Ann Neurol 37:657-664.

Fox K (2002) Anatomical pathways and molecular mechanisms for plasticity in the barrel cortex. Neuroscience 111:799-814.

Fox K, Glazewski S, Chen CM, Silva A, Li X (1996) Mechanisms underlying experience-dependent potentiation and depression of vibrissae responses in barrel cortex. J Physiol (Paris) 90:263-269.

Gamberino WC, Brennan Jr WA (1994) Glucose transporter isoform expression in Huntington's disease brain. J Neurochem 63:1392-1397.

Gardoni F, Caputi A, Cimino M, Pastorino L, Cattabeni F, Di Luca M (1998) Calcium/calmodulin-dependent protein kinase II is associated with NR2A/B subunits of NMDA receptor in postsynaptic densities. J Neurochem 71:1733-1741.

Glazewski S, Barth AL, Wallace H, McKenna M, Silva A, Fox K (1999) Impaired experience-dependent plasticity in barrel cortex of mice lacking the alpha and delta isoforms of CREB. Cereb Cortex 9:249-256.

Grafton ST, Mazziotta JC, Pahl JJ, George-Hyslop P, Haines JL, Gusella J, Hoffman JM, Baxter LR, Phelps ME (1990) A comparison of neurological, metabolic, structural, and genetic evaluations in persons at risk for Huntington's disease. Ann Neurol 28:614-621.

Guic-Robles E, Valdivieso C, Guajardo G (1989) Rats can learn a roughness discrimination using only their vibrissal system. Behav Brain Res 31:285-289.

Guic-Robles E, Jenkins WM, Bravo H (1992) Vibrissal roughness discrimination is barrelcortex-dependent. Behav Brain Res 48:145-152.

Gutekunst CA, Li SH, Yi H, Mulroy JS, Kuemmerle S, Jones R, Rye D, Ferrante RJ, Hersch SM, Li XJ (1999) Nuclear and neuropil aggregates in Huntington's disease: relationship to neuropathology. J Neurosci 19:2522-2534.

Hardingham GE, Fukunaga Y, Bading H (2002) Extrasynaptic NMDARs oppose synaptic NMDARs by triggering CREB shut-off and cell death pathways. Nat Neurosci 5:405-414.

Hardingham N, Glazewski S, Pakhotin P, Mizuno K, Chapman PF, Giese KP, Fox K (2003) Neocortical long-term potentiation and experiencedependent synaptic plasticity require $\alpha$-calcium/calmodulin-dependent protein kinase II autophosphorylation. J Neurosci 23:4428-4436.

Hodgson JG, Agopyan N, Gutekunst CA, Leavitt BR, LePiane F, Singaraja R, Smith DJ, Bissada N, McCutcheon K, Nasir J, Jamot L, Li XJ, Stevens ME, Rosemond E, Roder JC, Phillips AG, Rubin EM, Hersch SM, Hayden MR (1999) A YAC mouse model for Huntington's disease with full-length mutant huntingtin, cytoplasmic toxicity, and selective striatal neurodegeneration. Neuron 23:181-192.

Jablonska B, Gierdalski M, Siucinska E, Skangiel-Kramska J, Kossut M (1995) Partial blocking of NMDA receptors restricts plastic changes in adult mouse barrel cortex. Behav Brain Res 66:207-216.

Kirkwood SC, Siemers E, Stout JC, Hodes ME, Conneally PM, Christian JC, Foroud T (1999) Longitudinal cognitive and motor changes among presymptomatic Huntington disease gene carriers. Arch Neurol 56:563-568.

Kirkwood SC, Siemers E, Hodes ME, Conneally PM, Christian JC, Foroud T (2000) Subtle changes among presymptomatic carriers of the Huntington's disease gene. J Neurol Neurosurg Psychiatry 69:773-779.

Klapstein GJ, Fisher RS, Zanjani H, Cepeda C, Jokel ES, Chesselet MF, Levine MS (2001) Electrophysiological and morphological changes in striatal spiny neurons in r6/2 Huntington's disease transgenic mice. J Neurophysiol 86:2667-2677.

Kossut M, Glazewski S, Siucinska E, Skangiel-Kramska J (1993) Functional plasticity and neurotransmitter receptor binding in the vibrissal barrel cortex. Acta Neurobiol Exp (Wars) 53:161-173.

Kuhl DE, Phelps ME, Markham CH, Metter EJ, Riege WH, Winter J (1982) Cerebral metabolism and atrophy in Huntington's disease determined by 18FDG and computed tomographic scan. Ann Neurol 12:425-434.

Laforet GA, Sapp E, Chase K, McIntyre C, Boyce FM, Campbell M, Cadigan BA, Warzecki L, Tagle DA, Reddy PH, Cepeda C, Calvert CR, Jokel ES, Klapstein GJ, Ariano MA, Levine MS, DiFiglia M, Aronin N (2001) Changes in cortical and striatal neurons predict behavioral and electrophysiological abnormalities in a transgenic murine model of Huntington's disease. J Neurosci 21:9112-9123.

Lawrence AD, Hodges JR, Rosser AE, Kershaw A, ffrench-Constant C, Rubinsztein DC, Robbins TW, Sahakian BJ (1998) Evidence for specific cognitive deficits in preclinical Huntington's disease. Brain 121:1329-1341.

Lebedev MA, Mirabella G, Erchova I, Diamond ME (2000) Experiencedependent plasticity of rat barrel cortex: redistribution of activity across barrel-columns. Cereb Cortex 10:23-31.

Levine MS, Klapstein GJ, Koppel A, Gruen E, Cepeda C, Vargas ME, Jokel ES, Carpenter EM, Zanjani H, Hurst RS, Efstratiadis A, Zeitlin S, Chesselet MF (1999) Enhanced sensitivity to $N$-methyl- $D$-aspartate receptor activation in transgenic and knockin mouse models of Huntington's disease. J Neurosci Res 58:515-532.

Li JY, Plomann M, Brundin P (2003) Huntington's disease: a synaptopathy? Trends Mol Med 9:414-420.

Luthi-Carter R, Hanson SA, Strand AD, Bergstrom DA, Chun W, Peters NL, Woods AM, Chan EY, Kooperberg C, Krainc D, Young AB, Tapscott SJ, Olson JM (2002) Dysregulation of gene expression in the R6/2 model of polyglutamine disease: parallel changes in muscle and brain. Hum Mol Genet 11:1911-1926.

Mangiarini L, Sathasivam K, Seller M, Cozens B, Harper A, Hetherington C, Lawton M, Trottier Y, Lehrach H, Davies SW, Bates GP (1996) Exon 1 of the HD gene with an expanded CAG repeat is sufficient to cause a progressive neurological phenotype in transgenic mice. Cell 87:493-506.

Murphy KP, Carter RJ, Lione LA, Mangiarini L, Mahal A, Bates GP, Dunnett SB, Morton AJ (2000) Abnormal synaptic plasticity and impaired spatial cognition in mice transgenic for exon 1 of the human Huntington's disease mutation. J Neurosci 20:5115-5123.

Nucifora Jr FC, Sasaki M, Peters MF, Huang H, Cooper JK, Yamada M, Takahashi H, Tsuji S, Troncoso J, Dawson VL, Dawson TM, Ross CA (2001) Interference by huntingtin and atrophin-1 with cbp-mediated transcription leading to cellular toxicity. Science 291:2423-2428.

Paulsen JS, Ready RE, Hamilton JM, Mega MS, Cummings JL (2001) Neuropsychiatric aspects of Huntington's disease. J Neurol Neurosurg Psychiatry 71:310-314.

Rema V, Armstrong-James M, Ebner FF (1998) Experience-dependent plasticity of adult rat $\mathrm{S} 1$ cortex requires local NMDA receptor activation. J Neurosci 18:10196-10206.

Sax DS, Powsner R, Kim A, Tilak S, Bhatia R, Cupples LA, Myers RH (1996) Evidence of cortical metabolic dysfunction in early Huntington's disease by single-photon-emission computed tomography. Mov Disord 11:671-677.

Siucinska E, Kossut M (1996) Short-lasting classical conditioning induces reversible changes of representational maps of vibrissae in mouse SI cortex-a 2DG study. Cereb Cortex 6:506-513. 
Smith EE, Jonides J (1999) Storage and executive processes in the frontal lobes. Science 283:1657-1661.

Snell RG, MacMillan JC, Cheadle JP, Fenton I, Lazarou LP, Davies P, MacDonald ME, Gusella JF, Harper PS, Shaw DJ (1993) Relationship between trinucleotide repeat expansion and phenotypic variation in Huntington's disease. Nat Genet 4:393-397.

Sokoloff L, Reivich M, Kennedy C, Des-Rosiers MH, Patlak CS, Pettigrew KD, Sakurada O, Shinohara M (1977) The [14C]deoxyglucose method for the measurement of local cerebral glucose utilization: theory, procedure, and normal values in the conscious and anesthetized albino rat. J Neurochem 28:897-916.

Strominger RN, Woolsey TA (1987) Templates for locating the whisker area in fresh flattened mouse and rat cortex. J Neurosci Methods 22:113-118.
Tanji J, Hoshi E (2001) Behavioral planning in the prefrontal cortex. Curr Opin Neurobiol 11:164-170.

Urban J, Kossut M, Hess G (2002) Long-term depression and long-term potentiation in horizontal connections of the barrel cortex. Eur J Neurosci $16: 1772-1776$

Usdin MT, Shelbourne PF, Myers RM, Madison DV (1999) Impaired synaptic plasticity in mice carrying the Huntington's disease mutation. Hum Mol Genet 8:839-846.

Van Dellen A, Blakemore C, Deacon R, York D, Hannan AJ (2000) Delaying the onset of Huntington's in mice. Nature 404:721-722.

Vonsattel JP, Myers RH, Stevens TJ, Ferrante RJ, Bird ED, Richardson Jr EP (1985) Neuropathological classification of Huntington's disease. J Neuropathol Exp Neurol 44:559-577. 